\title{
Kvalifikaatiot ja valtiollisen perusopetuksen synty
}

Olen saanut aiheen tähän puheenvuoroon Heikki Lehtosen julkaisusta 'Palkkatyöläistyminen, kasvatuksen yhteiskunnallistuminen ja sosiaalipolitiikka", jossa tekijän tavoitteena on tarjota aineksia koulutussosiologiseen keskusteluun (Lehtonen 1984, ii). Itse näen keskustelun aihetta ennen kaikkea siinä, että Lehtonen esittää käyttämänsä teoreettisen näkökulman alan käsitteellisellä tasolla laajempana kuin se tosiasiassa on ja sen selitysvoiman koulutuspolitiikan historiallisessa tutkimuksessa aivan liian suurena.

Ennen edellä mainittujen kysymysten käsittelyä on syytä aluksi huomauttaa siitä, että Lehtosen tekstiin sisältyy lyhyt kuvaus länsisaksalaisen koulutustutkimuksen piirissä käydystä kvalifikaatiokeskustelusta, josta asiaa tarkemmin tuntematon lukija saa kovin yksinkertaistetun käsityksen. Lehtonen toteaa "koulutuksen poliittisen taloustieteen" suuntauksen rajoittuneen työn edellyttämien kvalifikaatioiden tarkasteluun (20-23; suluissa olevat numeroviittaukset tarkoittavat Lehtosen em. julkaisun sivuja). Koulutustutkimuksen ongelmanasettelun laajentamista työn ulkopuolella käytettävien kvalifikaatioiden suuntaan edustavat Lehtosen esityksessä (28) kaksi Georg Auernheimerin tekstiä, joissa työn ulkopuolisia kvalifikaatioita nimitetään ensin "kiertokulun" (Zirkulation) ja sitten (työvoiman) "uusintamisen" (Reproduktion) kvalifikaatioiksi (Auernheimer 1977a, 1980). Tällainen esityksellinen hyppäys koulutuksen poliittisen taloustieteen suuntauksen perusteksteistä eteenpäin ohittaa ne Auernheimeria varhaisemmat puheenvuorot, joissa tätä suuntausta arvosteltiin juuri työn ulkopuolisten kvalifikaatioiden tarkastelun puutteesta (esim. Baethge 1972 ja Offe 1975). Mainitun kritiikin viemisessä teoreettisten kehittelyjen suuntaan on Auernheimerilla sitten kyllä omat ansionsa.

Lehtosen oma ehdotus käsitteeksi, joka kuvaisi työn ulkopuolisissa toiminnoissa tarvittavia kvalifikaatioita, on "työvoiman uusintamisen edellyttämät kvalifikaatiot"' $(26-28,66)$.
Hän väittää tämän käsitteen kattavan tavaranvaihdon ja kulutuksen alueiden toimintojen sekä poliittisen toiminnan edellyttämät kvalifikaatiot, joiden erottamista kolmeksi eri kvalifikaatiotyypiksi olen itse pitänyt tarpeellisena (ks. Takala 1983, 21-23).

On tietysti mahdollista muotoilla jokin yleiskäsite edustamaan erilaisia kvalifikaatioita, joita työn ulkopuoliset toiminnot yhteiskunnassa edellyttävät - tässä tarkoituksessa voidaan puhua vaikkapa yksinkertaisesti työn ulkopuolisista kvalifikaatioista. Olennaisempi kysymys on se, että tällaisen yleiskäsitteen esittäminen ei suinkaan korvaa em. alemman abstraktiotason erottelua, koska työn ulkopuoliset kvalifikaatiot eroavat joissakin suhteissa selvästi toisistaan. Esimerkiksi kulutuksen alueen kvalifikaatioita - joihin käsite työvoiman uusintaminen selvimmin liittyy - voidaan hyvin kuvata termillä "itsekuri", joka tällöin tarkoittaa kykyä mukauttaa toiminnot työvoiman uusintamisehtojen asettamiin rajoihin (ks. emt., 32). Tämä termi ei nähdäkseni sen sijaan kuvaa sellaisia tavaranvaihdon tai poliittisen toiminnan edellyttämiä kvalifikaatioita kuin tavaranvaihdon yleisten periaatteiden tunnustaminen, kyky oman työvoiman esittelyyn tavarana, valtion legitimiteetin tunnustaminen ja poliittinen organisoituminen (ks. emt., 31-32, 34). Jos ei erota käsitteellisesti toisistaan kulutuksen ja tavaranvaihdon kvalifikaatioita sekä poliittisia kvalifikaatioita, jää samalla näkymättömiin se toimintaalueiden eriytyminen kapitalistisissa yhteiskunnissa, johon em. kvalifikaatiotyyppien väliset erot perustuvat.

Riippumatta edellä mainitusta ongelmasta on kuitenkin ilmeistä että Lehtosen tarjoama "työvoiman uusintamisen edellyttämien kvalifikaatioiden"' käsite ei mielekkäästi kata työn ulkopuolisten toimintojen kokonaisuutta. Tämän käsitteen perusteluun sisältyy paitsi kulutuksen alueen toimintojen redusoiminen työvoiman uusintamiseen, myös tavaranvaihdon redusoiminen työvoiman myyntiin ja politii- 
kan näkeminen vain "työvoiman uusintamisvajausten artikuloimisena poliittisen järjestelmän ratkaistaviksi" (27). Näistä rajauksista viimeksi mainittu on yllättävä sikäli, että vaikka Lehtosen lähteenä käyttämä. Auernheimer on keskittynyt tarkastelemaan ennen kaikkea tavaranvaihdon ja kulutuksen alueilla käytettäviä kvalifikaatioita, hän on kuitenkin teksteissään (Lehtosen mainitsemien 1977a ja 1980 lisäksi 1977b ja Auernheimer ym. 1979) käsitteellisesti erottanut poliittisen toiminnan ja sen edellyttämät kvalifikaatiot em. alueista. Tavaranvaihdon sisällyttäminen työvoiman uusintamisen käsitteen piiriin perustunee Lehtosella siihen ajatukseen että tullakseen uusinnettuna työprosessiin on työvoima-tavaran tultava myydyksi $(30,45-46)$. Toisesta kulmasta katsoen voidaan sen sijaan sanoa että työvoimatavaran myynti edellyttää työvoiman uusintamista (nämä eri tarkastelukulmat työvoiman myynnin ja sen uusintamisen väliseen suhteeseen ilmenevät edellä mainituissa Auernheimerin käsitteissä "'Reproduktionsqualifikation" ja "'Zirkulationsqualifikation", joiden ala on sama). Työvoiman uusintamiskvalifikaatioiden käsite näyttää siis viittaavan ensi sijassa kulutuksen alueen toimintoihin siltä osin kuin niitä voidaan pitää työvoiman uusintamisehtojen määrinä (vrt. Takala 1983, 38). Kaiken kaikkiaan tämän käsitteen merkitys työn ulkopuolisten kvalifikaatioiden problematiikan kannalta on siis vähäisempi kuin mitä Lehtonen esittää, eikä edes venytetyllä työvoiman uusintamiskvalifikaatioiden käsitteellä ole mahdollista korvata tavaranvaihdon/kulutuksen/poliittisten kvalifikaatioiden käsitteitä.

Työn ulkopuolisten kvalifikaatioiden käsitteellistä tarkastelua Lehtonen pyrkii hyödyntämään valtiollisen perusopetuksen syntyä koskevassa historiallisessa tarkastelussa. Hän esittää yleisen teesin, jonka mukaan "palkkatyöläistyminen" edellytti palkkatyöläisiltä "'lisääntyviä kvalifikaatioita työprosessin ulkopuolisten elämäntilanteiden hallintaa varten", ja toisaalta vähensi perheen mahdollisuuksia toimia em. kvalifikaatioiden muodostajana $(7$, 56). Siten palkkatyöläistymisen prosessi "näyttäisi selittävän huomattavassa määrin valtiollisen perusopetuksen syntyä ja kehitystä" (7-8). Valtiollisen perusopetuksen nähdään siis syntyneen "työvoiman uusintamiskvalifikaatioiden" muodostajaksi, korvaamaan tässä suhteessa toimintakykynsä menettänyttä perhekasvatusta. Tällaisesta näkökulmasta ovat sosiaalipolitiikan ja valtiollisen perusopetuksen historialliset juuret pitkälle yhtenevät, mikä paljastaa Lehtosen mukaan yhty- mäkohdan sosiaalipolitiikka-tieteen ja koulutuspolitiikan tutkimuksen välille $(2,69)$. Lähempi tarkastelu kuitenkin nähdäkseni osoittaa, että tämä yhtymäkohta on osin keinotekoisesti rakennettu ja että Lehtosen historiallisesta aineistostaan tekemät päätelmät ovat varsin vähän yleistettävissä koskemaan valtiollisen perusopetuksen synnyn ja palkkatyöläistymisprosessin välistä yhteyttä eri maissa.

Keinotekoiselta Lehtosen ajatuskulku näyttää siltä osin kuin hän puhuu ns. työvoiman regeneraatioon, eli uusien palkkatyöläisten sukupolvien tuottamiseen, liittyvistä intresseistä valtiollisen perüsopetuksen taustana. Hän toteaa ensinnäkin että palkkatyöläisväestöllä ei ollut "rationaalista regeneraatiointressiä" (48) eli ei ollut taloudellista hyötyä lasten hankkimisesta jättää tässä yhteydessä kokonaan huomiotta lasten ansiotulojen merkityksen palkkatyöläisperheiden taloudessa kapitalismin varhaisissa vaiheissa. Sen sijaan palkkatyöläisväestön kasvuun kohdistuvat pääomanomistajien intressit tekevät Lehtosen mukaan ymmärrettäväksi sen, että uskonnonopetuksella oli alkuun keskeinen asema valtiollisen perusopetuksen sisältönä $(38-39,49,67-68)$. Epäselväksi tässä kehittelyssä jää se, miten uskonnonopetus - joka ainakin Suomessa oli kansakoululaitoksen alkuvaiheessa lähinnä raamatunhistorian ja katekismuksen opettelemista ja joka seksuaalikysymyksissä suuntautui avioliiton ulkopuolisia suhteita vastaan pyrki edistämään ja/tai tosiasiassa edisti väestönkasvua verrattuna tilanteeseen ennen valtiollisen perusopetuksen syntyä. Uskottavalta tuntuu pikemmin päinvastaisen suuntainen ajatus, jonka mukaan lasten koulunkäynti vähensi palkkatyöläisvanhempien mahdollisuuksia hyötyä lastensa ansiotuloista ja valtiollisen perusopetuksen järjestäminen tätä kautta todennäköisesti rajoitti lasten syntymistä (ks. Donzelot 1979, 75-76).

Lehtosen käyttämä historiallisen aineisto kuvaa palkkatyöläistymisprosessia yksinomaan Englannissa. Hän katsoo Englannissa tapahtuneen kehityksen olevan "erityisen valaiseva" ja esittää tämän aineiston pohjalla päätelmänsä valtiollisen perusopetuksen yhteiskunnallisesta taustasta yleistyksinä $(57,68$ 69). Muiden maiden valtiollisen perusopetuksen historiaa hän ei näytä tuntevan. Esitettävien yleistysten relativointiin olisi kuitenkin antanut aihetta esimerkiksi jo tieto siitä, että Preussissa tämä opetus käynnistyi noin sata vuotta aiemmin kuin Englannissa (56). Suhteessa palkkatyöläistymisprosessien etenemi- 
seen näiden maiden välinen ero on vielä huomattavasti suurempi.

Tutkittaessa valtiollisen perusopetuksen synnyn yhteiskunnallista taustaa yleisesti ei Englanti nähdäkseni ole "erityisen valaiseva", vaan sen sijaan poikkeuksellinen tapaus. Englantia koskevasta aineistosta tehtävien päätelmien yleistettävyyttä voi tietenkin arvioida täsmällisesti vain tarkastelemalla konkreettisesti muissa maissa tapahtunutta kehitystä. Voi kuitenkin olettaa että eri maiden kesken on huomattavia eroja esimerkiksi siinä, kuinka pitkälle palkkatyöläisväestö on ollut työn ulkopuolella "vapaa" vs. patriarkaalisin suhtein sidoksissa työnantajaansa (vrt. 31-32; Takala 1983, 96-97), ja siinä, kuinka suurelta osin työvoiman uusintaminen on tapahtunut yksilöllis-perhekohtaisen itsekurin vs. palkkatyöläisväestön keskinäisen normatiivisen kontrollin alaisena (vrt. 30, 58; Takala 1983, 97). Tämänkaltaiset erot ovat todennäköisesti merkitseviä palkkatyöläistymisprosessin ja valtiollisen perusopetuksen synnyn välisen suhteen kannalta siten, että patriarkaaliset suhteet ja palkkatyöläisten keskinäinen kontrolli ovat vähentäneet tarvetta työn ulkopuolisten kvalifikaatioiden muodostamiseen koululaitoksen piirissä.

Samoin on ajatus palkkatyöläisperheiden kyvyttömyydestä työn ulkopuolella tarvittavien kvalifikaatioiden välittämiseen lapsille, mitä Lehtonen nimittää jopa "perheen tuhoutumiseksi sosialisaatioinstituutiona" (23), ehkä Englannin 1800-luvun oloja kuvaava (6061), mutta niiden ulkopuolelle ulottuvana yleistyksenä selvästi virheellinen. Esimerkiksi Suomessa oli naimisissaolevien naisten työssäkäynti maatalouden ulkopuolisen palkkatyöläisväestön keskuudessa suhteellisen harvinaista ennen kansakoululaitoksen syntyä ja kansakoulun varhaisvaiheiden aikana (ks. esim. Jallinoja 1980, 224-225, 228). Tässä yhteydessä on myös tärkeää huomata, että riippumatta palkkatyöläisperheiden kyvystä toimia kasvattajina ennen valtiollisen perusopetuksen syntyä on koululaitos kerran synnyttyään varmastikin vähentänyt vanhempien auktoriteettia suhteessa kouluakäyviin/käyneisiin lapsiin, jolloin koulunkäynnin päättäneiden lasten "joutilaisuus" ennen työhönmenoa on muodostunut kvalifikaatioiden ylläpitämisen kannalta ongelmaksi (tästä ks. Takala 1983, 132133). Haluamatta tarjota Suomea koskevaa arviota yleistettäväksi tuon vielä esiin Y.K. YrjöKoskisen v. 1894 kirjoittamasta artikkelista löytämäni toisenlaisen yhtymäkohdan koulutuspolitiikan ja sosiaalipolitiikan välille: 1800- luvun lopulla oli kunnallisen kiertokoulun opettajantoimet "usein uskottu semmoisten henkilöiden huostaan, jotka ilman tätä ansiotointa olisivat toisella tapaa kunnan elätettäviä', ja kiertokoulu oli "'etupäässä yksi laji kunnallista vaivaishoitoa" (Yrjö-Koskinen 1894; ks. myös Halila 1949, 64, 73-74).

Koska valtiollisen perusopetuksen synnyn ja palkkatyöläistymiskehityksen välinen yhteys siis näyttää olevan heikompi kuin mitä Lehtonen esittää, on tarpeen etsiä muita teoreettisia välineitä ensin mainitun ymmärtämiseksi. Vaihtoehtoinen - ei palkkatyöläistymisen tarkastelua poissulkeva, mutta useiden maiden kohdalla ilmeisen ensisijainen - näkökulma valtiollisen perusopetuksen syntyyn on kansallisvaltion kehitysprosessista lähtevä tarkastelu (ks. esim. Flora 1972; Takala 1984, 14-16). Tällaisessa tarkastelussa koulutus nähdään osana prosessia, jossa aiemmin vain erilaisiin pienryhmiin ja paikalliskulttuureihin samastuneiden ihmisten joukko muodostuu kansakunnaksi ja valtionkansalaisiksi. Kyse on tällöin osaksi sellaisten kvalifikaatioiden aikaansaamisesta, joita edellä esittämässäni jaottelussa nimitettiin poliittisiksi kvalifikaatioiksi (ja jotka siis eivät sisälly työvoiman uusintamiskvalifikaatioihin). Kuitenkin kansallisvaltion kehitykseen liittyy myös muun tasoisen merkitysjärjestelmän luominen, jossa perusopetuksella on keskeinen osuus kansallisen kielen ja muiden kansallisen kulttuurin symbolien vakiinnuttamisessa. Näitä merkityksiä ei voida tavoittaa teoreettisesti marxilaisen kapitalismikonseption puitteissa.

Koululaitoksen merkitys valtionkansalaisten toiminnan edellyttämien poliittisten kvalifikaatioiden aikaansaamisessa sekä kansallisen kulttuurin symbolien vakiinnuttamisessa tekee ymmärrettäväksi sen, että 'kansalle"' tarkoitettu koulujärjestelmä muodostui nimenomaan valtiolliseksi perusopetukseksi - sen sijaan työvoiman uusintamiskvalifikaatioiden aikaansaaminen ei mitenkään välttämättä näytä edellyttävän pikemmin valtiollista kuin työnantajien tai filantrooppisten järjestöjen organisoimaa opetusta. Kansallisvaltion kehitysprosessin kannalta voidaan myös ymmärtää valtiollisen perusopetuksen syntyä ilman väittämiä "perheen tuhosta sosialisaatioinstituutiona", koska tuhoutumatonkin perhekasvatus oli joka tapauksessa partikularistista suhteessa tähän prosessiin, eli perheen potentiaalinen merkitys kasvattajana oli kouluun verrattuna rajoitettu. Nämä seikat ovat tärkeä tausta esimerkiksi sille Fichten aikanaan esittämälle vaatimukselle että saksalaiset lapset olisi kasvatet- 
tava perheistään erotettuina valtiollisissa sisäoppilaitoksissa - sen sijaan Lehtosen ajatuskulun mukaan tulee tämäkin selitetyksi yksinkertaisesti palkkatyöläistymisprosessilla ja sen vaikutuksilla perhekasvatukseen (32-33; vrt. esim. Godefroid ym. 1974, 217-222).

Edellä toteamani Englannin poikkeuksellisuus tulee ilmi siinä, että kansallisvaltion kehitysprosessi ei ole kovinkaan tärkeä tutkittaessa valtiollisen perusopetuksen syntyä Englannissa, mutta sen sijaan se on olennainen monien muiden maiden - Euroopassa esimerkiksi Preussin, Ranskan ja Pohjoismaiden - kohdalla. Jotta käsityksemme edellä mainittujen ja muiden teoreettisten näkökulmien käyttökelpoisuuden aloista eivät jäisi yksittäistapauksiin pohjautuvien spekulaatioiden varaan, tarvitaan sekä eri teorioita vertailevaa että eri maita vertailevaa koulutuspolitiikan ja koulutusjärjestelmien tutkimusta. Tällaisia tutkimuksia on jo olemassa, mutta ne eivät näytä olevan kovinkaan tunnettuja suomalaisten koulutustutkijoiden keskuudessa (ks. Flora emt.; Collins 1977; Archer 1979; Ringer 1979; Ramirez \& Meyer 1982; Schneider 1982).

\section{Kirjallisuus}

Archer, Margaret: Social Origins of Educational Systems, London 1979.

Auernheimer, Georg: Mündigkeit und Allgemeinbildung als Erziehungsanforderungen der bürgerlichen Gesellschaft. Demokratische Erziehung 3 (1977):3, s. 291-304 (1977 a).

Auernheimer, Georg: Zirkulationsqualifikation. Päd. extra (1977):8, s. 18-23 (1977 b).

Auernheimer, Georg: Die Vergesellschaftung der Erziehung. Teoksessa Braun, Karl-Heinz (hrsg.): Materialistische Pädagogik, Köln 1980.

Auernheimer, Georg \& Böhnke, Wolfgang \& Dörr, Günter \& Schubert, Volker: Reproduktionsqualifikation als eine Determinante von Pädagogik und Bildungspolitik. Teoksessa 30 Jahre Bildungspolitik, Arguments-Sonderbände Nr. 38, Westberlin 1979.

Baethge, Martin: Abschied von Reformillusionen. Betrifft: Erziehung (1972):11, s. 19-28.
Collins, Randall: Some Comparative Principles of Educational Stratification. Harvard Educational Review 47 (1977):1, s. 1-27.

Donzelot, Jacques: The Policing of Families, London 1979.

Flora, Peter: Die Bildungsentwicklung im Prozess der Staaten- und Nationenbildung. Kölner Zeitschrift für Soziologie und Sozialpsychologie, Sonderheft Nr. 16, 1972, s. 294-319.

Godefroid, Susanne \& Kölling, Christian \& Timm, Wolfgang \& Tristram-Düsterbeck, Dorothea: Bürgerliche Ideologie und Bildungspolitik. Das Bildungswesen in Preussen vom Ausgang des 18. Jahrhunderts bis zur bürgerlichen Revolution 1848/49, Giessen 1974.

Halila, Aimo: Suomen kansakoululaitoksen historia, I, Turku 1949.

Jallinoja, Riitta: Miehet ja naiset. Teoksessa Valkonen, Tapani ym.: Suomalaiset, Juva 1980.

Lehtonen, Heikki: Palkkatyöläistyminen, kasvatuksen yhteiskunnallistuminen ja sosiaalipolitiikka. Yhteiskuntatieteiden tutkimuslaitos, Tampereen yliopisto, Sarja B 39/1984.

Offe, Claus: Bildungssystem, Beschäftigungssystem und Bildungspolitik. Teoksessa Bildungsforschung: Probleme - Perspektiven - Prioritäten, Deutscher Bildungsrat, Gutachten und Studien der Bildungskommission, Band 50, Stuttgart 1975.

Ramirez, Francisco \& Meyer, John: Comparative Education: the Social Construction of the Modern World System. Annual Review of Sociology, 6, 1982, s. 369-399.

Ringer, Fritz: Education and Society in Modern Europe, Bloomington 1979.

Schneider, Reinhart: Die Bildungsentwicklung in den westeuropäischen Staaten 1879-1975. Zeitschrift für Soziologie 11 (1982):3, s. 207226.

Takala, Tuomas: Oppivelvollisuuskoulu ja yhteiskunnalliset intressit. Acta Universitatis Tamperensis, Ser. A., 151, 1983.

Takala, Tuomas: Vertailevasta koulutuspolitiikan ja koulutusjärjestelmien tutkimuksesta. Tampereen yliopiston sosiologian ja sosiaalipsykologian laitoksen työraportteja, Sarja B 8/1984.

Yrjö-Koskinen, Y.K.: Oppipakko ja koulupakko. Kansakoulun Lehti, 15.1.1894. 